MALTHW MALUETRA

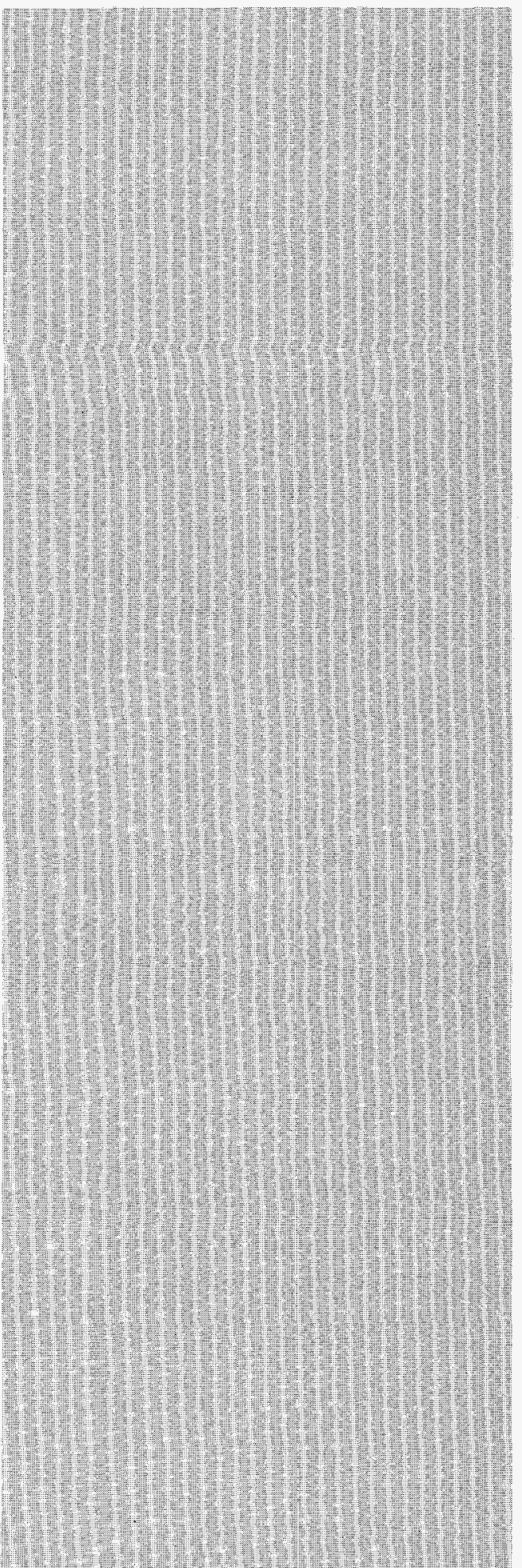

MANAGED BY

MARTII MARIETTA ENERGY SYSTEYS, IIIC. FOR THQTUIILEPSTATES DEPARTMENT OF ENERGY

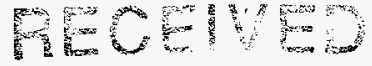

DEC 191995

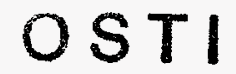

Y/SUB/95-99069C/K49/1

\section{SITE STATUS MONITORING REPORT FOR UNDERGROUND STORAGE TANK 2331-U AT BUILDING 9201-1}

\author{
OAK RIDGE Y-12 PLANT \\ OAK RIDGE, TENNESSEE \\ FACILITY ID \#0-010117
}

January 1995

Environmental Management Department Health, Safety, Environment, and Accountability Organization 


\section{DISCLAIMER}

This report was prepared as an account of work sponsored by an agency of the United States Government. Neither the United States Government nor any agency thereof, nor any of their employees, makes any warranty, express or implied, or assumes any legal liability or responsibility for the accuracy, completeness, or usefulness of any information, apparatus, product, or process disclosed, or represents that its use would not infringe privately owned rights. Reference herein to any specific commercial product, process, or service by trade name, trademark, manufacturer, or otherwise, does not necessarily constitute or imply its endorsement, recommendation, or favoring by the United States Government or any agency thereof. The views and opinions of authors expressed herein do not necessarily state or reflect those of the United States Government or any agency thereof.

\section{SCIENCE APPLICATIONS NTERNATIONAL CORPORATION}

contributed to the Freparation of this document and should not be conidered an eligible contractor for is review. 


\section{DISCLAMMER}

Portions of this document may be illegible in electronic image products. Images are produced from the best available original document. 


\title{
SITE STATUS MONITORING REPORT FOR UNDERGROUND STORAGE TANK 2331-U AT BUILDING 9201-1
}

\author{
OAK RIDGE Y-12 PLANT \\ OAK RIDGE, TENNESSEE \\ FACILITY ID \#0-010117
}

\author{
January 1995 \\ Environmental Management Department \\ Health, Safety, Environment, \\ and Accountability Organization
}

Prepared by

Science Applications International Corporation

Under Subcontract 22B-99069C

for the

Oak Ridge Y-12 Plant

Oak Ridge, Tennessee 37831

\section{Managed by}

Martin Marietta Energy Systems, Inc.

for the

U.S. Department of Energy

Under Contract No. DE-AC05-84OR21400 
LIST OF FIGURES

1. INTRODUCTION

1.1 Purpose and Scope

2. GROUNDWATER MONITORING

2.1 Groundwater Measurement, Sample Collection, and Analysis

2.1.1 Well Locations

2.1.2 Groundwater Measurement and Sampling

2.1.3 Sample Analysis

2.2 Potentiometric Data

$2-1$

2.3 Groundwater Analytical Data

$2-6$

3. VAPOR MONITORING

3-1

3.1 Monitoring Method and Locations

3-1

3.2 Vapor Monitoring Results.

3-1

\section{REFERENCES}

R-1

\section{APPENDICES}

Appendix A Laboratory Analytical Results for Site Status Monitoring 


\section{LIST OF FIGURES}

Figure Title

1-1 Location of the Building 9201-1 Site at the Y-12 Plant ............................................ 1-2

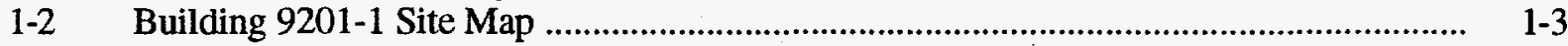

2-1 Building 9201-1 Site Monitoring Well Location Map ................................................... 2-2

2-2 Building 9201-1 Site Groundwater Potentiometric Contour Map Dec. 1994 .................. 2-4

2-3 Building 9201-1 Site Groundwater Potentiometric Contour Map June $1994 \ldots \ldots \ldots \ldots . . . . . . . . . \quad 2-5$

3-1 Building 9201-1 Site Vapor Monitoring Sampling Location Map................................. 3-2

Table $\quad \underline{\text { Title }}$

\section{LIST OF TABLES}

2-1 Water level measurements at the Building 9201-1 Site for the periods of June 1994 and Dec.1994

2-2 Analytical results for groundwater samples collected during site status and comprehensive monitoring, baseline sampling, and 1993 groundwater quality assessment sampling ......

3-1 Vapor monitoring results for the Building 9201-1 Site, December 20, 1994 


\section{LIST OF ACRONYMS}

BGS below ground surface

BTEX benzene, toluene, ethylbenzene, and xylenes

BTOC below top of casing

CAP Corrective Action Plan

GRO gasoline range organic

LEL lower explosive limit

MSL mean sea level

TDEC Tennessee Department of Environment and Conservation

TPH total petroleum hydrocarbon

TWA time weighted average

UEFPC Upper East Fork Poplar Creek

UST underground storage tank 


\section{SIGNATURE PAGE}

I certify under penalty of law, including but not limited to penalties for perjury, that the information contained in this report and on any attachments, is true, accurate, and complete to the best of my knowledge, information, and belief. I am aware that there are significant penalties for submitting false information, including the possibility of fine and imprisonment for intentional violations.

See Attached Certification

Owner/Operator (Print)

William D. Keefer

P.E. or P.G. (Print)

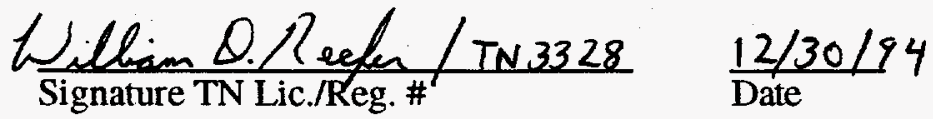

If a P.E. signs this report, please indicate the area of expertise.

Professional Geologist

(Print or Type)

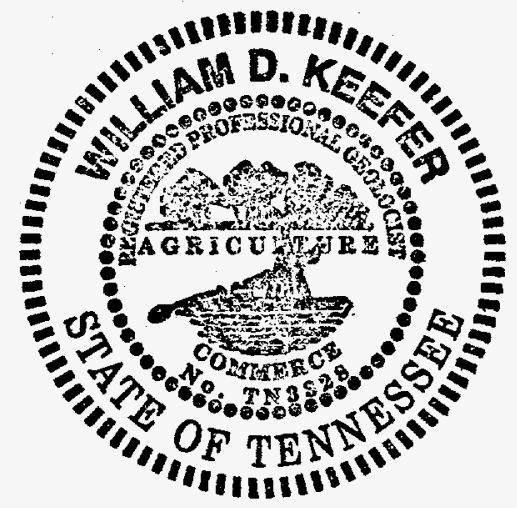

(P.E./P.G. Stamp/Seal)

County of LAuderson.

State of

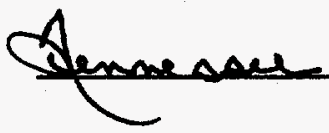

Subscribed and Sworn to before me this

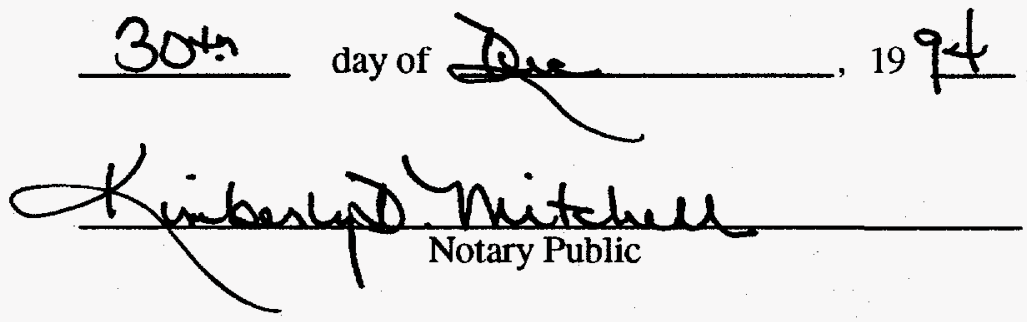

My Commission expires:

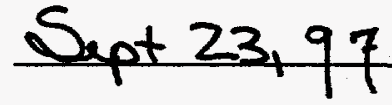

(Notary Seal) 


\section{CERTIFICATION STATEMENT FOR THE \\ SITE STATUS MONITORING REPORT FOR \\ THE UNDERGROUND STORAGE TANK 2331-U, AT BUILDING 9201-1}

I certify that this document and all enclosures were prepared under my direction or supervision in accordance with a system designed to ensure that qualified personnel properly gather and evaluate the information submitted. Based on my inquiry of the person or persons directly responsible for gathering the information, the information submitted is, to the best of my knowledge and belief, true, accurate, and complete.

U.S. Department of Energy

Owner and Operator

By:
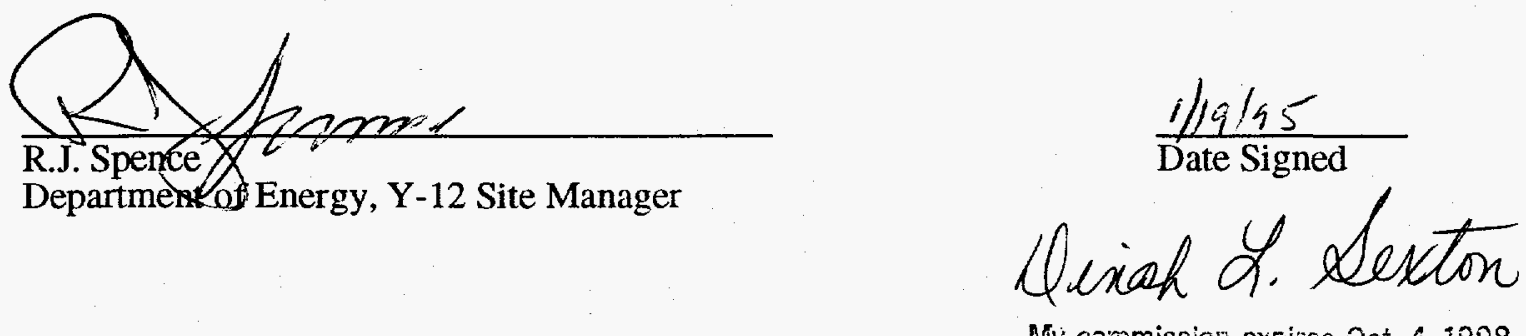

Martin Marietta Energy Systems, Inc.

Co-Operator

By:

T.R. Butz

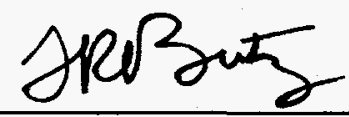

Martin Marietta Energy Systems, Inc.

Y-12 Plant Manager 


\section{INTRODUCTION}

\subsection{Purpose and Scope}

The purpose of this document is to present potentiometric, groundwater quality and vapor monitoring data required for site status monitoring of underground storage tank (UST) 2331-U at the Building 9201-1 Site. Site status monitoring has been conducted at the site as part of a Monitoring Only program approved by the Tennessee Department of Environment and Conservation (TDEC) based on review and approval of Site Ranking (Site Ranking Form approved May 23, 1994). This document presents the results of the first semiannual site status monitoring that was performed in December 1994. Site status monitoring and preparation of this report have been conducted in accordance with the requirements of TDEC Rule 12001-15 and the TDEC UST Reference Handbook, Second Edition (TDEC 1994) Technical Guidance Document (TGD) 007 .

This document is organized into three sections. Section 1 presents introductory information relative to the site including the regulatory initiative and a site description. Section 2 includes the results of measurement and sampling of monitoring wells GW-193, GW-657, GW-707, GW-708, GW-808, GW809 , and GW-810. Section 3 presents data from vapor monitoring conducted in subsurface utilities present at the site.

\subsection{Site Description}

The Building 9201-1 Site is located within the south central portion of the Oak Ridge Y-12 Plant in Oak Ridge, Tennessee (Figure 1-1). This area is within the Exclusion Zone of the Y-12 Plant, which is access restricted. The site is generally defined as the area directly south of the Building 9201-1 concrete ramp/loading dock (Figure 1-2). The site was previously the location of a gasoline UST used to fuel gasoline-powered equipment in the area. The tank has been excavated and removed from the site.

The UST was a 560-gallon gasoline tank that was first suspected of leaking in 1988. Tightness testing confimed that the tank was leaking and the tank was subsequently excavated and removed. An Initial Site Characterization and Environmental Assessment identified the presence of petroleum contamination above applicable TDEC Closure Action Levels. A Corrective Action Plan (CAP) was prepared and approved and Baseline Monitoring was performed in support of corrective action (11/93). However, site ranking performed in accordance with the newly issued TGD-014 (1/94) indicated that contaminant concentrations were sufficiently low and contaminant exposure sufficiently limited in extent to qualify for a monitoring only program in lieu of active remediation.

The topography of the Building 9201-1 Site gently decreases in elevation from north to south across the facility. A surface water and groundwater divide coincident with the trace of Upper East Fork Poplar Creek (UEFPC) lies approximately $230 \mathrm{ft}$ south of the site. Given the nature of the surface topography at the Building 9201-1 Site, any petroleum contamination resulting from past UST operations would be expected to migrate south/southeast away from the source area. 


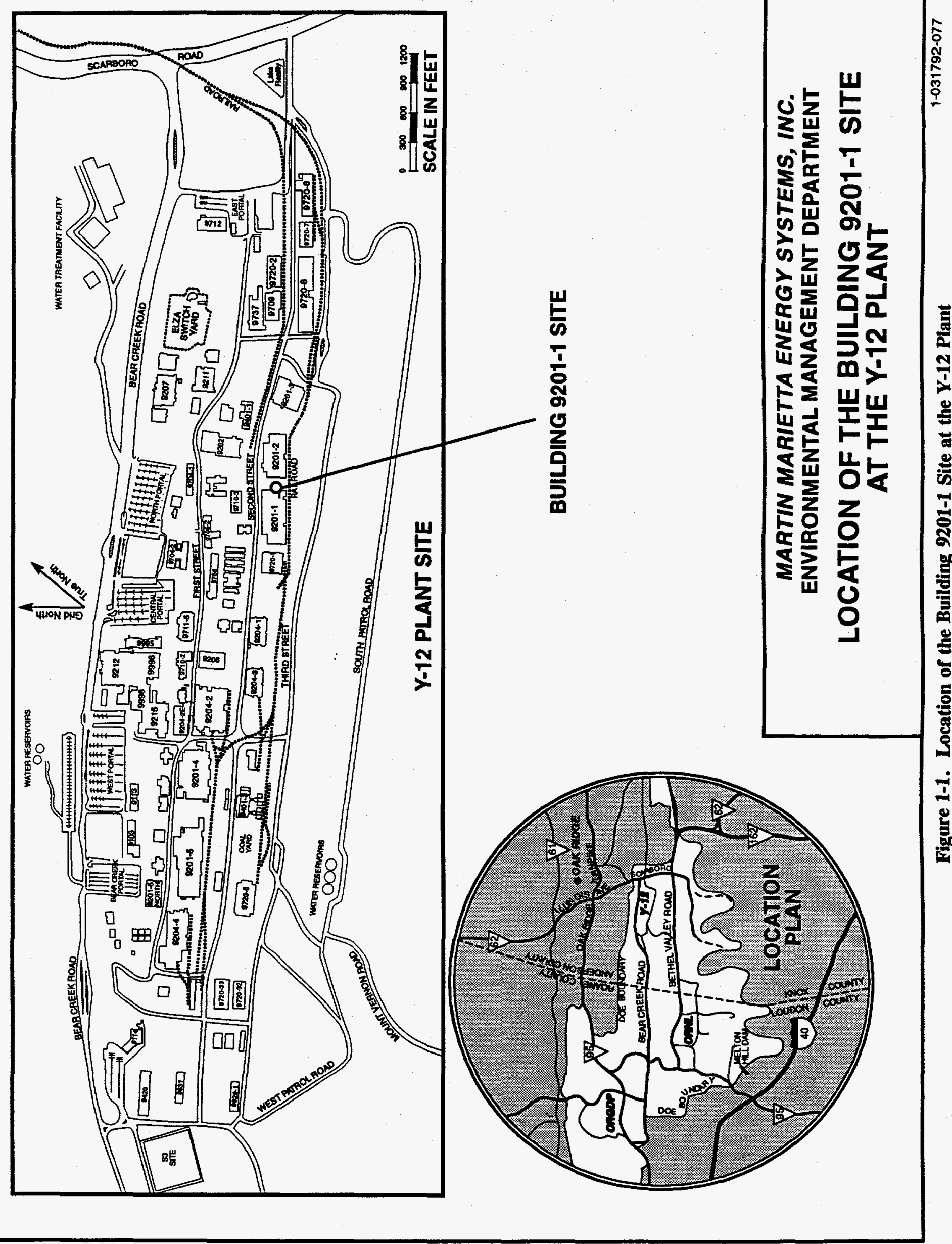




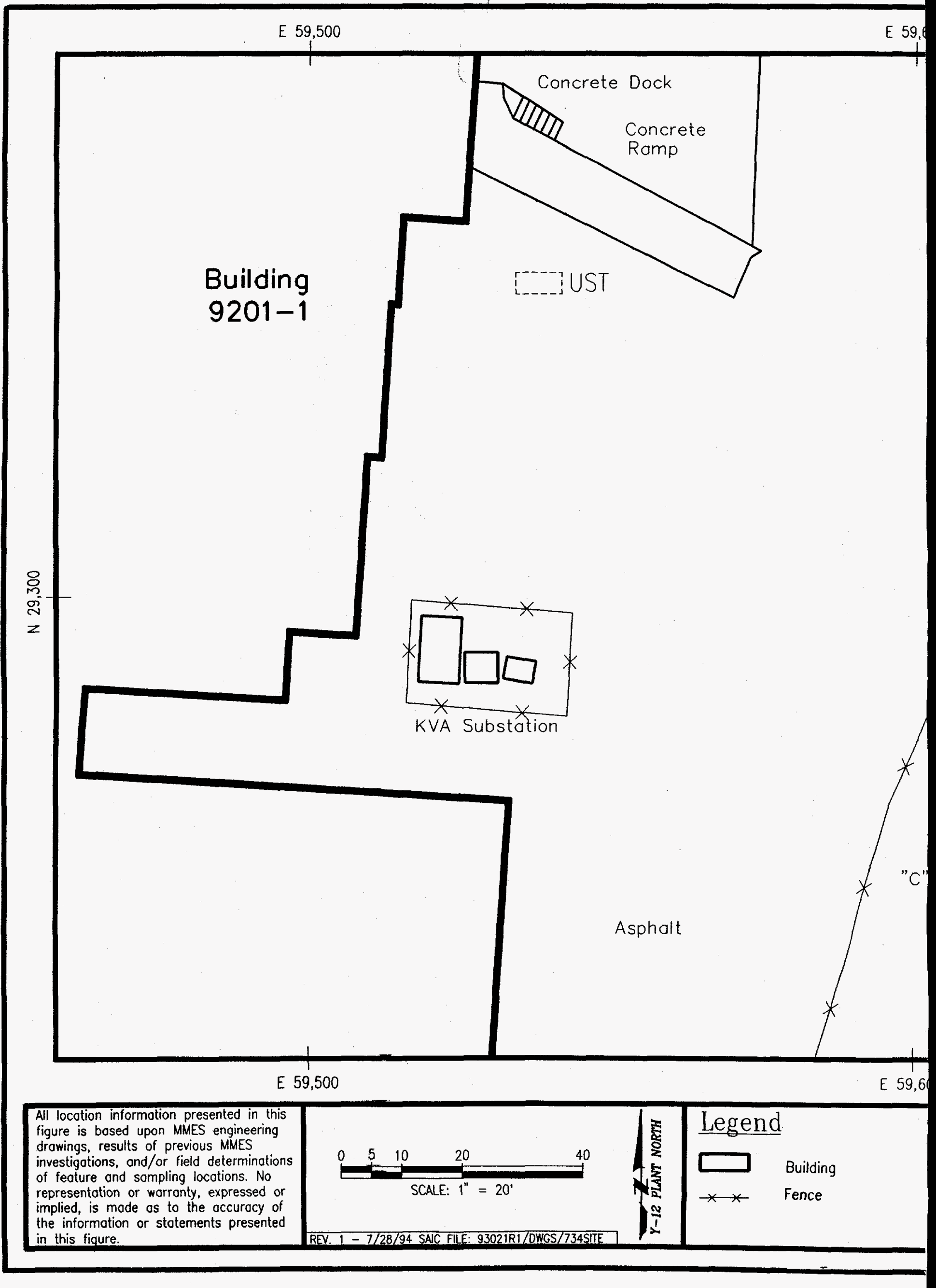




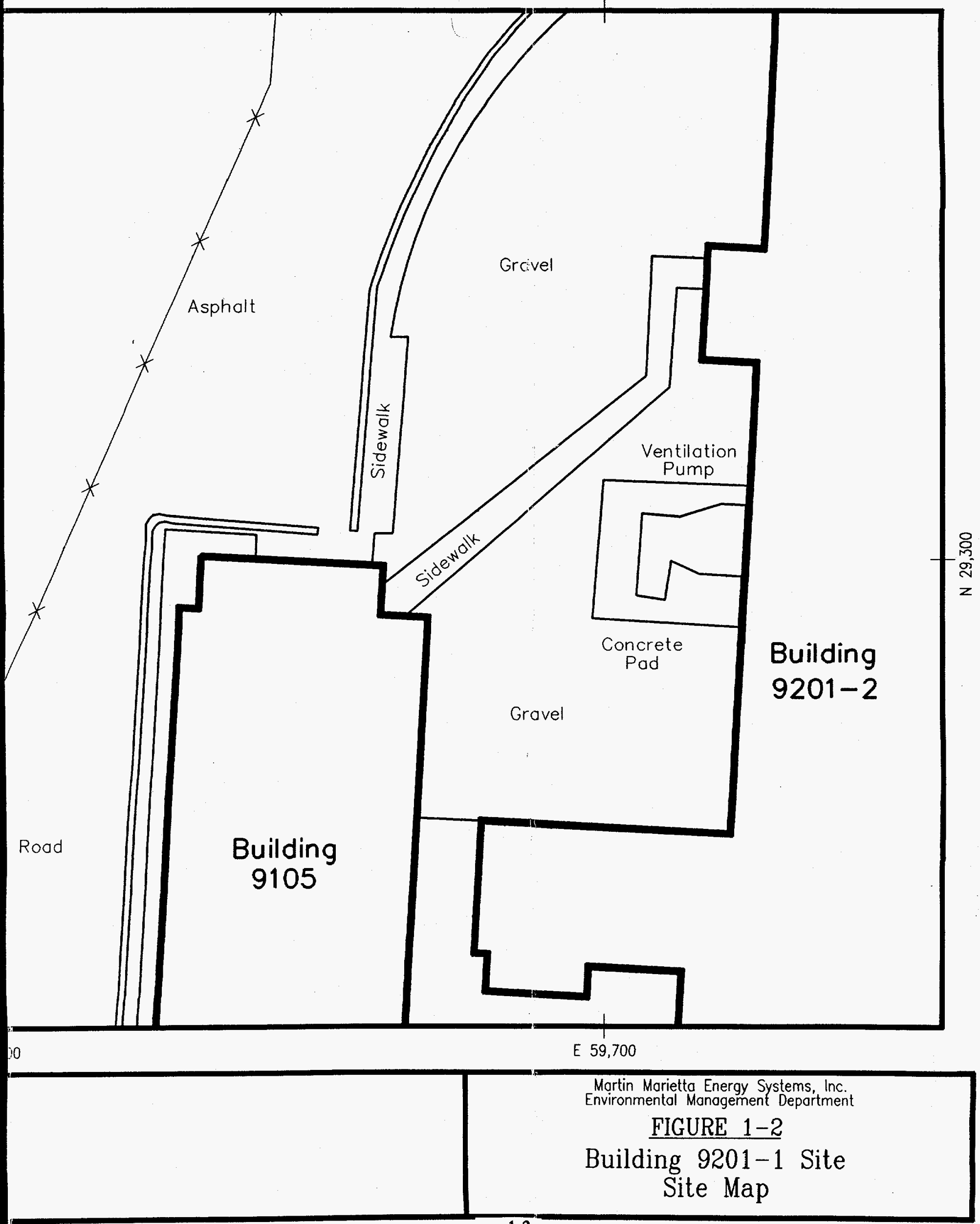




\section{GROUNDWATER MONITORING}

\subsection{Groundwater Measurement, Sample Collection, and Analysis}

\subsubsection{Well Locations}

Seven wells identified by TDEC have been measured and sampled as part of the Monitoring Only program for the site. These wells include GW-193, GW-657, GW-707, GW-708, GW-808, GW-809, and GW-810. The locations of these wells are presented in Figure 2-1. Well installation reports and construction details for monitoring wells GW-193, GW-657, GW-707, and GW-708 are presented in the CAP for the Site [Corrective Action Plan for Underground Storage Tank 2331-U at the Building 9201-1 Site, Appendix C, Y/SUB-92-99928C/3 (Energy Systems 1992)]. Well installation reports and construction details for monitoring wells GW-808, GW-809, and GW-810 that were installed in July 1993 are presented in the Corrective Action Baseline Report for the Site [Corrective Action Baseline Report for Underground Storage Tank 2331-U, Building 9201-1, Appendix A, Y/SUB/94-99069C/Y15/2 (Energy Systems 1994)].

\subsubsection{Groundwater Measurement and Sampling}

Current groundwater level measurement and sampling of the monitoring wells at the Building 9201-1 Site occurred on June 21, 1994 and December 14, 1994. Water levels were measured to the nearest $0.01 \mathrm{ft}$ using an electronic water level indicator. Each well was then purged of three well volumes prior to sampling except CW-707, which was purged to dryness after the removal of approximately two well volumes and was sampled as soon as sufficient volume had recovered. Field measurement of $\mathrm{pH}$, conductivity, temperature, and dissolved oxygen was conducted during purging to ensure representativeness for sampling. Monitoring wells GW-808, GW-809, and GW-810 had elevated $\mathrm{pH}(>10.0)$, but this is not expected to affect analytical results. No measurable free product was encountered during water level measurement or sampling in any of these wells. However, an oily sheen and petroleum odor were observed during purging and sampling of wells GW-193 and GW-708. Samples were collected using a boiler and transferred into pre-cleaned glass containers with zero headspace.

\subsubsection{Sample Analysis}

Groundwater samples were analyzed for total petroleum hydrocarbons-gasoline range organics (TPHGRO), and for benzene, toluene, ethylbenzene, and xylenes (BTEX) at the Y-12 Plant Environmental Laboratory (a TDEC Division of UST approved laboratory).

\subsection{Potentiometric Data}

Potentiometric data for monitoring wells at the Building 9201-1 Site from the comprehensive and site status monitoring measurement events are presented in Table 2-1. Figures 2-2 and 2-3 present potentiometric contour maps from these two periods. These figures indicate an irregular potentiometric surface with locally variable groundwater flow directions. A localized water table high southeast of the former UST site (around wells GW-707 and GW-657) appear to be reasonably persistent. This water table high may be related to a subsurface feature (e.g., fracture) or may reflect a small difference in head between unconsolidated and bedrock wells. However, the general flow direction, for any petroleum contaminants entering groundwater from the former UST depicted for both periods of measurement, is from north to south across the site. 


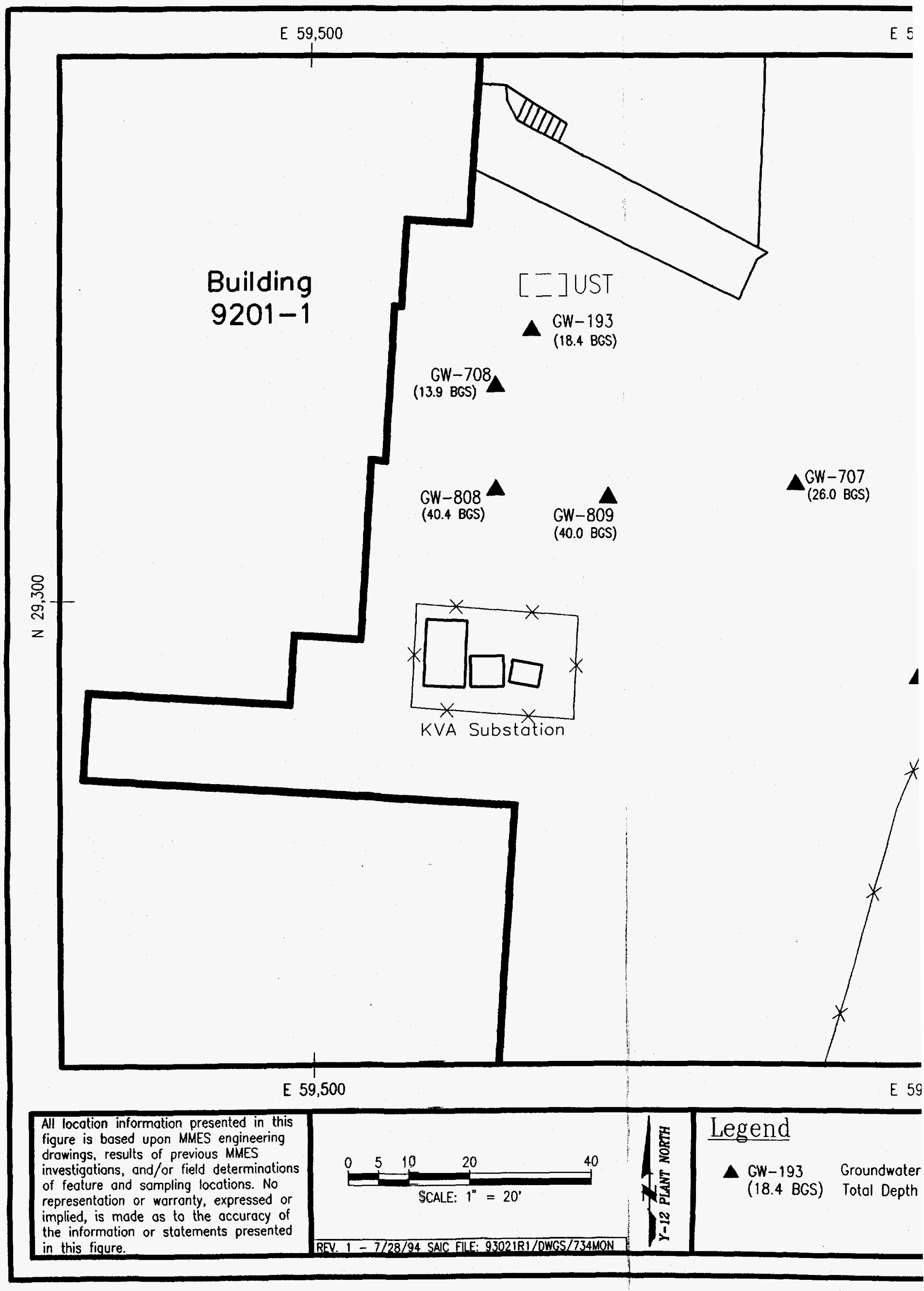




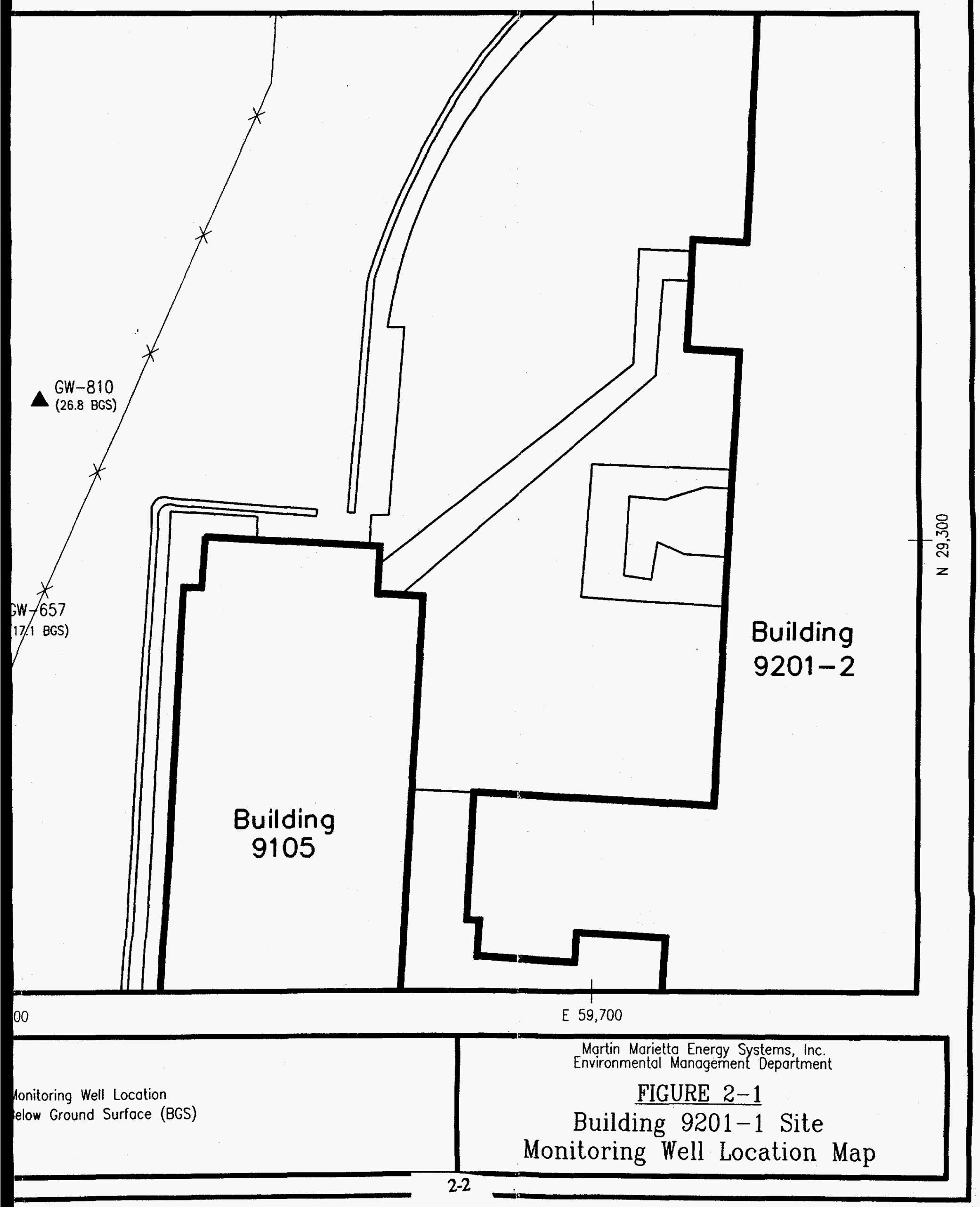


Table 2-1. Water level measurements at the Building 9201-1 Site for the periods of June and December 1994

\begin{tabular}{lccccc}
\hline $\begin{array}{c}\text { Monitoring } \\
\text { well number }\end{array}$ & $\begin{array}{c}\text { Date } \\
\text { measured }\end{array}$ & $\begin{array}{c}\text { Total well } \\
\text { depth } \\
\text { (ft-BGS) }\end{array}$ & $\begin{array}{c}\text { Top of } \\
\text { casing } \\
\text { (ft-MSL) }\end{array}$ & $\begin{array}{c}\text { Top of casing } \\
\text { to water level } \\
\text { (ft-BTOC) }\end{array}$ & $\begin{array}{c}\text { Potentiometric } \\
\text { surface elevation } \\
\text { (ft-MSL) }\end{array}$ \\
\hline GW-193 & $6 / 21 / 94$ & 18.4 & 934.00 & 8.20 & 925.80 \\
& $12 / 14 / 94$ & 18.4 & 934.00 & 8.07 & 925.93 \\
GW-657 & $6 / 21 / 94$ & 17.1 & 930.53 & 6.90 & 923.63 \\
& $12 / 14 / 94$ & 17.1 & 930.53 & 6.30 & 924.23 \\
GW-707 & $6 / 21 / 94$ & 26.0 & 930.91 & 5.70 & 925.21 \\
& $12 / 14 / 94$ & 26.0 & 930.91 & 6.20 & 924.71 \\
GW-708 & $6 / 21 / 94$ & 13.9 & 930.87 & 4.60 & 926.27 \\
& $12 / 14 / 94$ & 13.9 & 930.87 & 4.64 & 926.23 \\
GW-808 & $6 / 21 / 94$ & 40.4 & 930.75 & 7.87 & 922.88 \\
& $12 / 14 / 94$ & 40.4 & 930.75 & 8.30 & 922.45 \\
GW-809 & $6 / 21 / 94$ & 40.0 & 931.04 & 8.46 & 922.58 \\
& $12 / 14 / 94$ & 40.0 & 931.04 & 9.20 & 921.84 \\
GW-810 & $6 / 21 / 94$ & 26.8 & 931.44 & 9.69 & 921.75 \\
& $12 / 14 / 94$ & 26.8 & 931.44 & 8.95 & 922.49 \\
\hline
\end{tabular}

Notes:

BGS - below ground surface

MSL - mean sea level

BTOC - below top of casing 


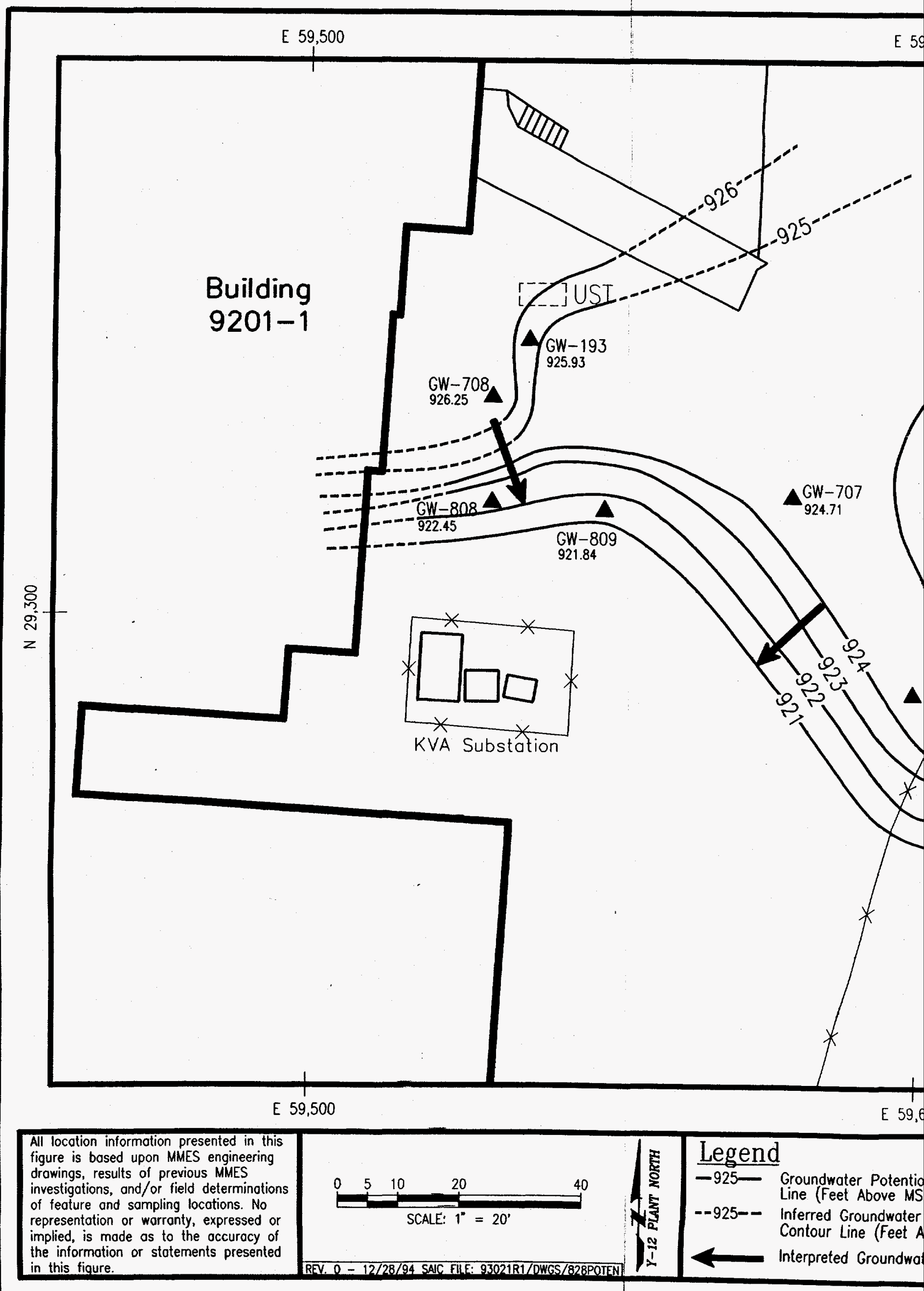




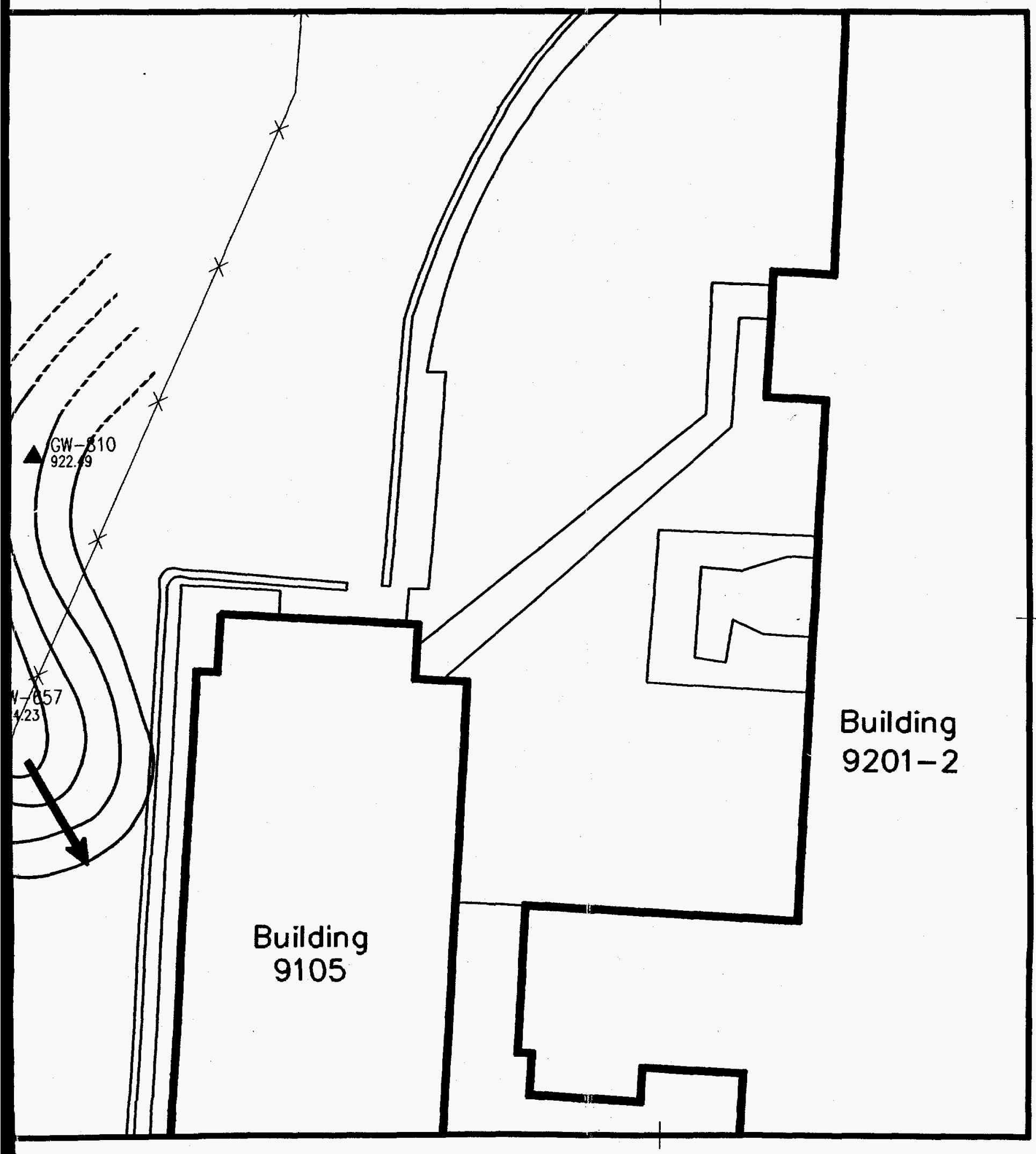

E 59,700

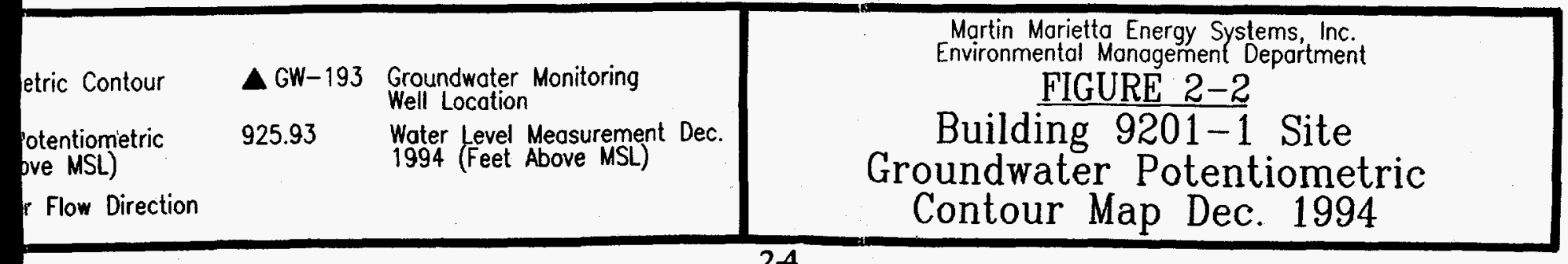




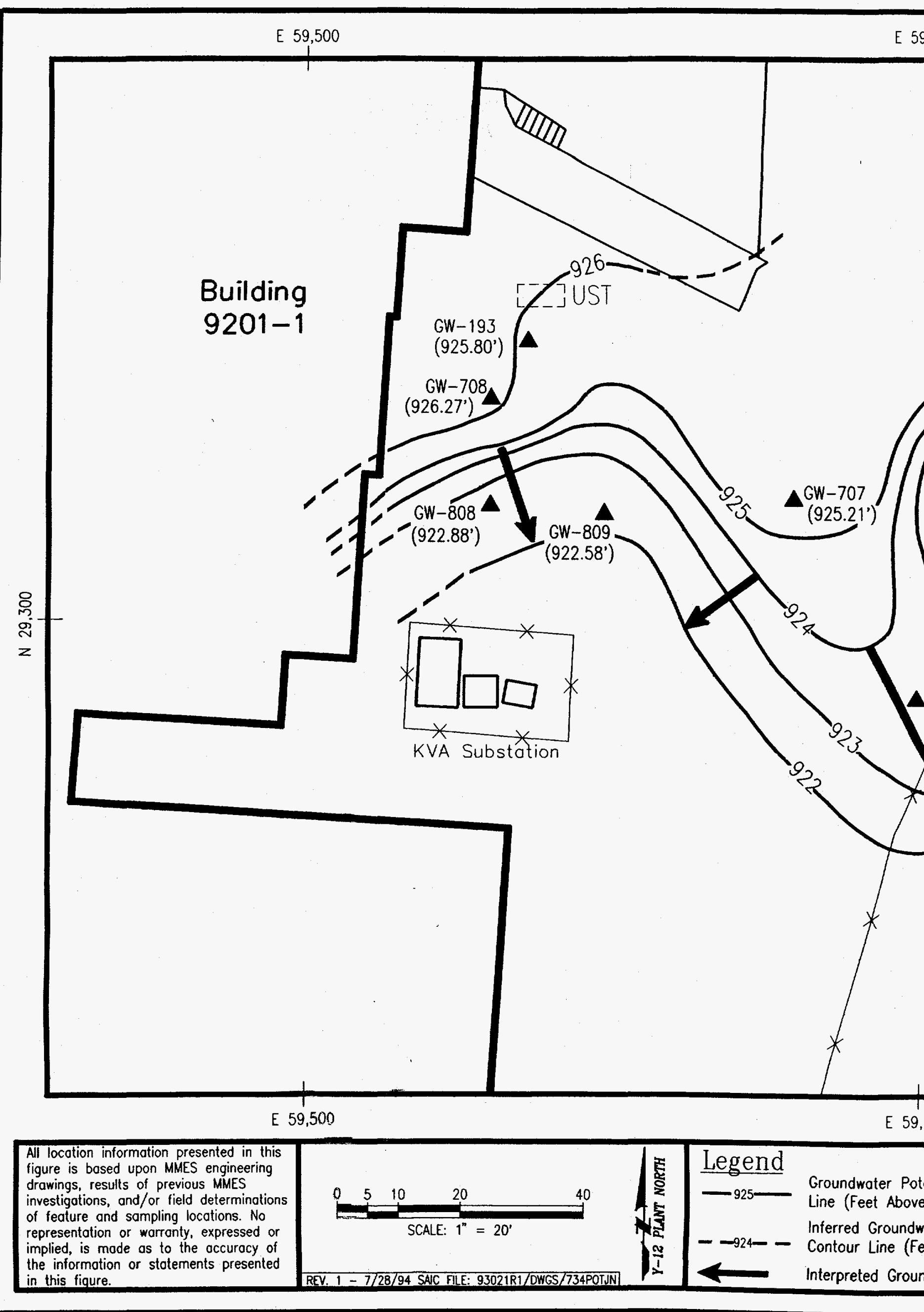




\subsection{Groundwater Analytical Data}

Analytical data for groundwater sampled at the site during site status and comprehensive monitoring, baseline sampling, and the last round of 1993 Upper East Fork Poplar Creek Hydrogeologic Regime Groundwater Quality Assessment sampling are presented in Table 2-2. Analytical results for the site status monitoring did not indicate any significant increase or decrease in the level of contamination as compared to historical monitoring. Benzene and TPH values for GW-193 and GW-708 continued to exceed the applicable Closure Action Levels of $0.07 \mathrm{ppm}$ for benzene and $1.0 \mathrm{ppm}$ for TPH, Both of these wells have historically produced values in excess of these closure limits. These results produce no change in the horizontal area of groundwater contamination as defined by the comprehensive monitoring data. Analytical results for GW-657, GW-707, GW-808, GW-809, and GW-810 show no groundwater contamination detected above analytical quantitation limits, which are below the applicable Closure Action Levels. These data indicate that groundwater contamination has not migrated downgradient to the location of these wells, and suggests the area of groundwater contamination is relatively stable over time.. This is consistent with previous monitoring results and the calcualted hydraulic gradient, velocity, and conductivity from slug testing of wells GW-193 and GW-707 (Energy Systems 1992). It is expected that contaminant elvels will fall of slowly as contaminant degradation continues because of the slow migration and limited mixing of the contaminated groundwater. 
Table 2-2. Analytical results for groundwater samples collected during site status and comprehensive monitoring, baseline sampling, and 1993 groundwater quality assessment sampling

\begin{tabular}{|c|c|c|c|c|c|c|}
\hline Sampling event & Sampling date & $\begin{array}{c}\text { TPH-GRO }^{1} \\
(\mathrm{ppm})\end{array}$ & $\begin{array}{c}\text { Benzene } \\
\text { (ppm) }\end{array}$ & $\begin{array}{l}\text { Ethylbenzene } \\
\text { (ppm) }\end{array}$ & $\begin{array}{c}\text { Toluene } \\
\text { (ppm) }\end{array}$ & $\begin{array}{l}\text { Xylenes } \\
\text { (ppm) }\end{array}$ \\
\hline \multicolumn{7}{|c|}{ GW-193 } \\
\hline $\begin{array}{l}\text { Site stanus } \\
\text { monitoring } \\
\text { Comprehensive }\end{array}$ & $12-14-94$ & $* 3.000$ & $* 0.620$ & 0.320 & $0.230 \mathrm{~B}^{2}$ & $0.360 \mathrm{~B}$ \\
\hline monitoring & 6-21-94 & $* 4.100$ & $* 0.420$ & 0.400 & 0.200 & 0480 \\
\hline Basline sampling & $11-2-93$ & $* 5.50$ & $* 1.68 \mathrm{E}^{3}$ & 0.575 & 0.235 & 0.353 \\
\hline 1993 GWQAR-Qtr. 4 & $11-18-93$ & *3.223 & $* 2.800$ & 0.450 & 0.700 & 0.580 \\
\hline \multicolumn{7}{|c|}{$G W-657$} \\
\hline $\begin{array}{l}\text { Site status } \\
\text { monitoring } \\
\text { Comprehensive }\end{array}$ & $12-14-94$ & $<0.100$ & $.010 \mathrm{U}$ & $.010 \mathrm{U}$ & $.010 \mathrm{U}$ & $.010 \mathrm{U}$ \\
\hline monitoring & 6-21-94 & $0.100 U^{4}$ & $0.010 \mathrm{U}$ & $0.010 \mathrm{U}$ & $0.010 \mathrm{U}$ & $0.010 \mathrm{U}$ \\
\hline Baseline sampling & $11-2-93$ & $<0.100$ & $<0.001$ & $<0.001$ & $<0.001$ & $<0.001$ \\
\hline 1993 GWQAR-Qtr. 4 & $11-15-93$ & 0.0049 & $0.005 \mathrm{U}$ & $0.005 \mathrm{U}$ & $0.005 \mathrm{U}$ & $0.005 \mathrm{U}$ \\
\hline \multicolumn{7}{|c|}{ GW-707 } \\
\hline $\begin{array}{l}\text { Site status } \\
\text { monitoring } \\
\text { Comprehensive }\end{array}$ & $12-14-94$ & $<0.100$ & $.010 \mathrm{U}$ & $.010 \mathrm{U}$ & $.010 \mathrm{U}$ & $.010 \mathrm{U}$ \\
\hline monitoring & $6-21-94$ & $0.042 \mathrm{~J}^{5}$ & $0.002 \mathrm{~J}$ & $0.010 \mathrm{U}$ & $0.010 \mathrm{U}$ & $0.001 \mathrm{~J}$ \\
\hline Baseline sampling ${ }^{6}$ & $11-2-93$ & $<0.100$ & $<0.001$ & $<0.001$ & $<0.001$ & $<0.001$ \\
\hline 1993 GWQAR-Qtr. 4 & $11-18-93$ & 0.0103 & $0.005 \mathrm{U}$ & $0.005 \mathrm{U}$ & $0.005 \mathrm{U}$ & $0.005 \mathrm{U}$ \\
\hline \multicolumn{7}{|c|}{ GW-708 } \\
\hline $\begin{array}{l}\text { Site status } \\
\text { monitoring } \\
\text { Comprehensive }\end{array}$ & $12-14-94$ & $* 5.300$ & $* 0.820$ & 0.610 & $0.094 \mathrm{~B}$ & $1.200 \mathrm{~B}$ \\
\hline monitoring & $6-21-94$ & *5.300 & $* 0.980$ & 0.620 & 0.110 & 0.690 \\
\hline Baseline sampling ${ }^{6}$ & $11-2-93$ & $* 7.50$ & $* 0.900$ & 0.800 & 0.095 & 1.575 \\
\hline 1993 GWQAR-Qtr. 4 & $11-12-93$ & $* 5.995$ & ${ }^{*} 0.780$ & 0.670 & 0.098 & 1.800 \\
\hline \multicolumn{7}{|c|}{ GW-808 } \\
\hline $\begin{array}{l}\text { Site status } \\
\text { monitoring } \\
\text { Comprehensive }\end{array}$ & $12-14-94$ & $<0.100$ & $0.010 \mathrm{U}$ & $0.010 \mathrm{U}$ & $0.010 \mathrm{U}$ & $<.010 \mathrm{~B}$ \\
\hline monitoring & $6-21-94$ & $0.012 \mathrm{~J}$ & $0.010 \mathrm{U}$ & $0.010 \mathrm{U}$ & $0.010 \mathrm{U}$ & $0.006 \mathrm{~J}$ \\
\hline Baseline sampling & $11-2-93$ & 0.140 & $<0.001$ & 0.016 & $<0.001$ & 0.111 \\
\hline \multicolumn{7}{|c|}{ GW-809 } \\
\hline $\begin{array}{l}\text { Site status } \\
\text { monitoring } \\
\text { Comprehensive }\end{array}$ & $12-14-94$ & $<0.100$ & $0.010 \mathrm{U}$ & $0.010 \mathrm{U}$ & $0.010 \mathrm{U}$ & $0.010 \mathrm{U}$ \\
\hline monitoring & 6-21-94 & 0.010 & $0.010 \mathrm{U}$ & $0.010 \mathrm{U}$ & $0.010 \mathrm{U}$ & $0.010 \mathrm{U}$ \\
\hline Baseline sampling & $11-2-93$ & $<0.100$ & 0.001 & 0.003 & 0.001 & 0.016 \\
\hline \multicolumn{7}{|c|}{$G W-810$} \\
\hline $\begin{array}{l}\text { Site status } \\
\text { monitoring } \\
\text { Comprehensive }\end{array}$ & $12-14-94$ & $<0.100$ & $0.010 \mathrm{U}$ & $0.010 \mathrm{U}$ & $0.010 \mathrm{U}$ & $0.010 \mathrm{U}$ \\
\hline monitoring & $6-21-94$ & $0.021 \mathrm{~J}$ & $0.010 \mathrm{U}$ & $0.010 \mathrm{U}$ & $0.010 \mathrm{U}$ & $0.010 \mathrm{U}$ \\
\hline Baseline sampling & $11-2-93$ & 0.190 & 0.001 & 0.019 & 0.001 & 0.136 \\
\hline
\end{tabular}

${ }^{1}$ TPH-GRO - Total Petroleum Hydrocarbons-Gasoline Range Organics.

${ }^{2} \mathrm{~B}$ - Indicates the analyte was found in the associated blank as well as in the sample.

${ }^{3} \mathrm{E}$ - Benzene exceeded calibration range.

${ }^{4} \mathrm{U}$ - Contaminant was not detected above quantition limit during the analysis.

${ }_{5}^{5}$ - Value estimated for contaminant.

${ }^{6}$ Sample identification error suspected. Baseline sample results for wells GW-707 and GW-708 have been transposed to correct this error.

*Denotes contamination above the applicable closure action levels for the site ( $1.0 \mathrm{ppm} \mathrm{TPH}, 0.070 \mathrm{ppm}$ benzene). 


\section{VAPOR MONITORING}

\subsection{Monitoring Methods and Locations}

Vapor monitoring as part of the Monitoring Only program has been conducted at seven access points along subsurface stormwater and sewer drainage lines that cross the Building 9201-1 Site. However, none of the subsurface utilities present at the site crosses the groundwater plume defined by the most recent data. The locations of vapor monitoring locations are illustrated in Figure 3-1.

At each location, the atmosphere was monitored using direct reading instruments. Organic vapors were measured using a Thermo Environmental ${ }^{\mathrm{TM}}$ organic vapor meter. Oxygen and lower explosive limit (LEL) were monitored .

\subsection{Vapor Monitoring Results}

The results of site status vapor monitoring conducted December 20, 1994 at the Building 9201-1 Site are presented in Table 3-1. Measured oxygen percentages are within the range of normal air concentrations. LEL readings of $0 \%$ indicate that an explosion hazard does not exist within any of the monitored utilities. Organic vapor readings range from $0.1 \mathrm{ppm}$ to $0.6 \mathrm{ppm}$ above background. These results are not considered indicative of the presence of measureable petroleum contamination, but may be due to the presence of residual petroleum contamination or other organic compounds (naturally occurring or man-made) at the site. However, the non-discriminatory nature of the organic vapor meter used in monitoring does not allow specific identification of the source.

Table 3-1. Vapor monitoring results for the Building 9201-1 Site,

December 20, 1994

\begin{tabular}{lcccc}
\hline $\begin{array}{c}\text { Sampling } \\
\text { location }\end{array}$ & $\begin{array}{c}\mathrm{O}_{2} \\
\%\end{array}$ & $\begin{array}{c}\text { LEL } \\
\%\end{array}$ & $\begin{array}{c}\text { Organic vapors } \\
(\mathrm{ppm})\end{array}$ & $\begin{array}{c}\text { Background organic } \\
\text { vapors } \\
(\mathrm{ppm})\end{array}$ \\
\hline $402 \mathrm{~A}$ & 20.8 & 0 & 0.5 & 0.0 \\
409 & 20.8 & 0 & 0.3 & 0.0 \\
$\mathrm{C}-4019$ & 20.8 & 0 & 0.1 & 0.0 \\
$\mathrm{C}-4021$ & 20.8 & 0 & 0.3 & 0.0 \\
$\mathrm{C}-4112$ & 20.8 & 0 & 0.3 & 0.0 \\
$\mathrm{C}-4111$ & 20.8 & 0 & 0.7 & 0.1 \\
$\mathrm{C}-4024$ & 20.8 & 0 & 0.1 & 0.0
\end{tabular}




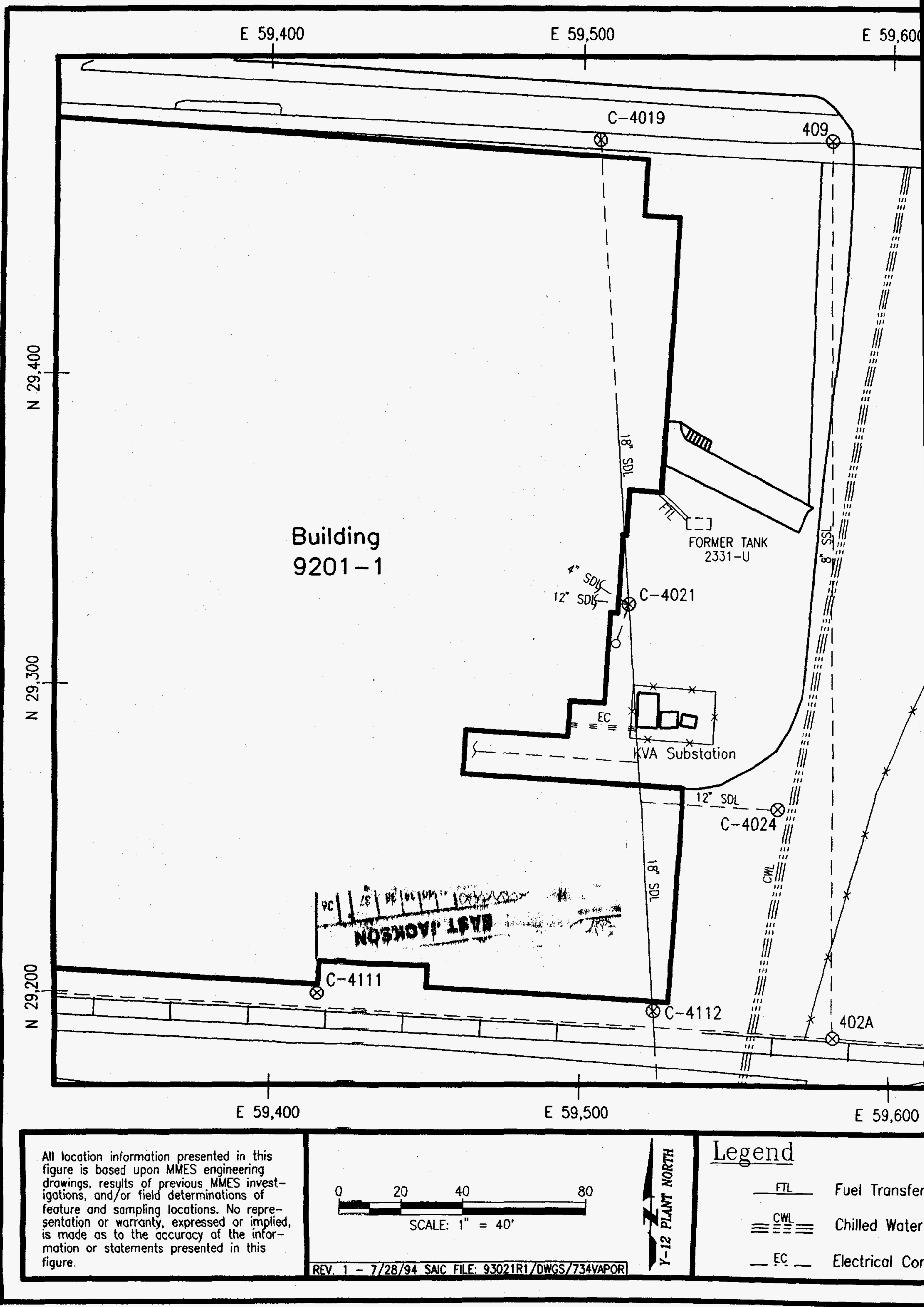




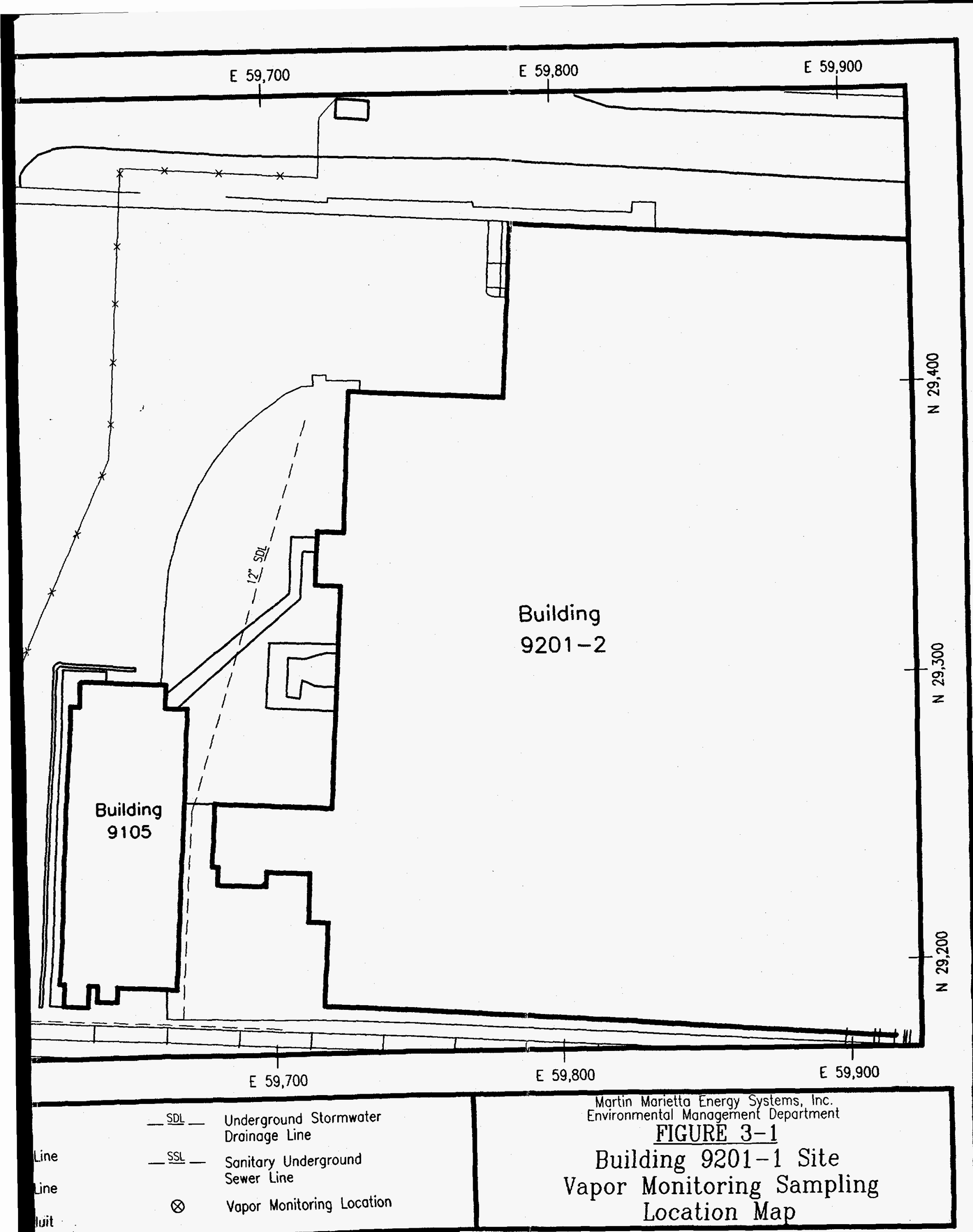




\section{REFERENCES}

American Conference of Govemmental Industrial Hygienists 1993-1994. The 1993-1994 Threshold Limit Values for Chemical Substances and Physical Agents and Biological Exposure Indices, ISDN: 1882417-03-8.

Energy Systems (Martin Marietta Energy Systems, Inc.) 1992. Corrective Action Plan for Underground Storage Tank 2331-U at the Building 9201-1 Site, Y/SUB-92-99928C/3.

Energy Systems 1994. Corrective Action Baseline Report for Underground Storage Tank 2331-U, Building 9201-1, Y/SUB/94-99069C/Y15/2.

TDEC (Tennessee Department of Environment and Conservation) 1994. Underground Storage Tank Reference Handbook, Second Edition. 
APPENDIX A

LABORATORY ANALYTICAL RESULTS FOR SITE STATUS MONITORING 


\section{UNCLASSIFIED}

OFFICIAL REPORT

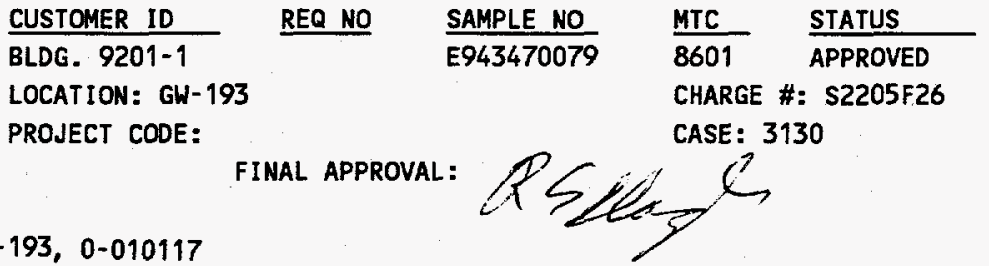

\section{MITTER}

rman, Donald Edwa

E SAMPLED: $12 / 14 / 94$ 11:11:00

E RECEIVED: $12 / 15 / 94$

PLER: 029776
CUSTOMER ID MS 8219

DATE NEEDED: $12 / 29 / 94$

DATE COMPLETED: $12 / 22 / 94$

SAMPLE DESCRIPTION: GRAB

\section{ADDRESS}

MENTS: UST WELL AT BLDG. 9201-1. DON BOHRMAN GETS RESULTS, GH-193, 0-010117
T: GRO TPH Gasol ine Range Organics Including BTEX

P MTH:

PROC MTH: SW846 8020
REPLICATE: 1

TIME ANALYZED: 12/21/94 10:35:00 APPROVER: E030124
NUMBER

32

414

883

0207

\section{DETERMINATION}

Gasol ine Range Organics

Benzene

Ethylbenzene

Toluene

Xylene

GRO Quantitation Limit

BTEX Quantitation Limit

GRO Amount in Blank
DT

\begin{tabular}{l} 
RESULT \\
\hline 3000 \\
620 \\
320 \\
$230 \mathrm{~B}$ \\
$360 \mathrm{~B}$ \\
400 \\
40 \\
NONE
\end{tabular}

CONFIDENCE

UNIT

$u g / L$

$u g / L$

ug/L

ug/L

$u g / L$

ug/L

$u g / L$

$u g / L$ 


\section{UNCLASSIFIED}

OFFICIAL REPORT

04/95 11:12:19

Y-12 ANALYTICAL SERVICES ORGANIZATION

PAGE 1 OF 1

MITTER

rman, Donald Edwa

ADDRESS

Building 9115 MS 8219

DATE NEEDED: $12 / 29 / 94$

DATE COMPLETED: $12 / 22 / 94$

SAMPLE DESCRIPTION: GRAB

CUSTOMER ID
BLDG. $9201-1$
LOCATION: GW-657
PROJECT CODE:

CUSTOMER ID

PROJECT CODE:

FINAL APPROVAL:

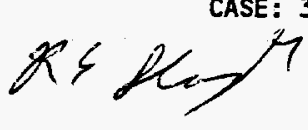

MENTS: UST HELLS AT 9201-1. RESULTS GO TO DON BOHRMAN, GW-657, 0-010117

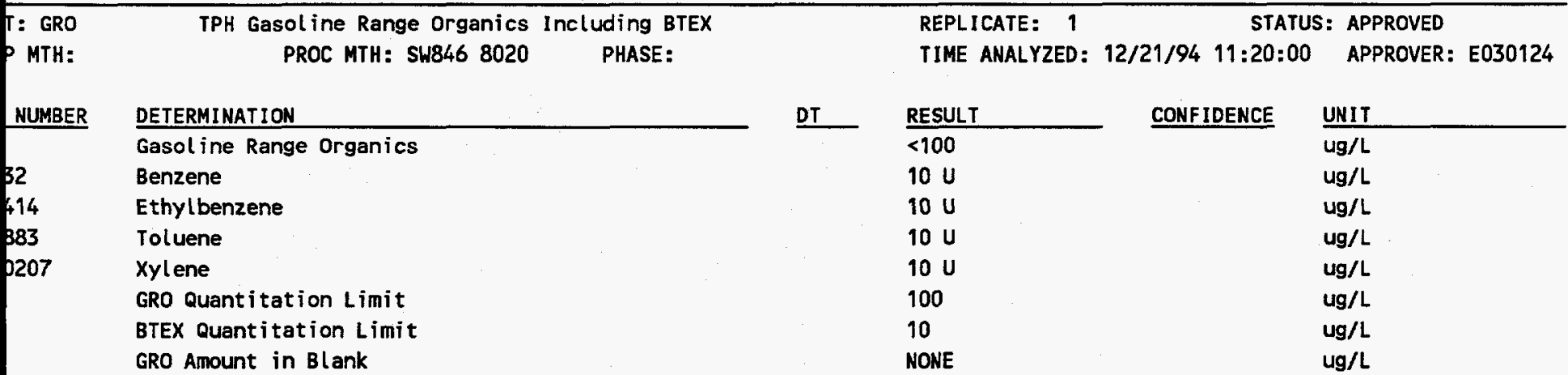




\section{UNCLASSIFIED}

OFFICIAL REPORT

\section{MITTER}

rman, Donald Edwa

E SAMPLED: $12 / 14 / 94 \quad 14: 45: 00$

E RECEIVED: $12 / 15 / 94$

PLER: 29776

MENTS:

Ust

T: GRO

P MTH:

TPH Gasol ine Range Organics Including BTEX

PROC MTH: SW846 8020

PHASE :

CUSTOMER ID BLDG. 9201-1

LOCATION: GW-707

PROJECT CODE:

$\frac{\text { SAMPLE NO }}{\text { E943470081 }}$

MTC STATUS

8601 APPROVED

CHARGE \#: S2205F26

CASE: 3130
DATE COMPLETED: 12/22/94

SAMPLE DESCRIPTION: GRAB
STATUS: APPROVED
NUMBER

32

414

883

0207

\section{DETERMINATION}

Gasol ine Range Organics

Benzene

Ethylbenzene

Toluene

Xylene

GRO Quantitation Limit

BTEX Quantitation Limit

GRO Amount in Blank
FINAL APPROVAL:

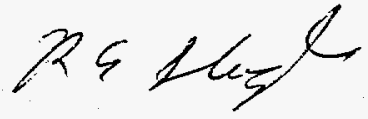

REPLICATE: 1

TIME ANALYZED: 12/21/94 12:09:00 APPROVER: E030124

DT

\begin{tabular}{l} 
RESULT \\
\hline$<100$ \\
$10 \mathrm{U}$ \\
$10 \mathrm{U}$ \\
$10 \mathrm{U}$ \\
$10 \mathrm{U}$ \\
100 \\
10 \\
NONE
\end{tabular}

CONFIDENCE

UNIT

ug/L

ug/L

ug/L

ug/L

$u g / L$

ug/L

ug/L

ug/L 


\section{UNCLASSIFIED}

OFFICIAL REPORT

MITTER

rman, Donald Edwa

E SAMPLED: $12 / 14 / 94$ 10:45:00

E RECEIVED: $12 / 15 / 94$

PLER: 29776

MENTS: UST WELL AT BLDG. 9201-1. RESULTS GO TO DON BOHRMAN, GW-708, 0-010117

\section{ADDRESS}

Building 9115 MS 8219

DATE NEEDED: $12 / 29 / 94$

DATE COMPLETED: $12 / 22 / 94$

SAMPLE DESCRIPTION: GRAB

\begin{tabular}{|c|c|c|c|c|}
\hline CUSTOMER ID & REQ NO & SAMPLE NO & MTC & STATUS \\
\hline BLDG. 9201-1 & & E943470082 & 8601 & APPROVED \\
\hline LOCATION: GW-708 & & & CHARC & : $\$ 2205 F 26$ \\
\hline
\end{tabular}

FINAL APPROVAL:
T: GRO TPH Gasol ine Range Organics Including BTEX

P MTH: PROC MTH: SW846 8020

PHASE :
REPLICATE: 1

STATUS: APPROVED

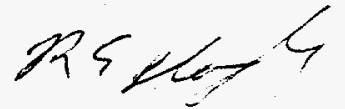

NUMBER

32

414

383

0207

\section{DETERMINATION}

Gasol ine Range Organics

Benzene

Ethylbenzene

Toluene

Xylene

GRO Quantitation Limit

BTEX Quantitation Limit

GRO Amount in Blank
TIME ANALYZED: 12/21/94 16:06:00 APPROVER: E030124

DT

\begin{tabular}{l} 
RESULT \\
\hline 5300 \\
820 \\
610 \\
948 \\
$1200 \mathrm{~B}$ \\
500 \\
50 \\
NONE
\end{tabular}

CONFIDENCE

UNIT

$\mathrm{ug} / \mathrm{L}$

$\mathrm{ug} / \mathrm{L}$

$u g / L$

$\mathrm{Ug} / \mathrm{L}$

ug/L

$\mathrm{ug} / \mathrm{L}$

$u g / L$

ug/L 


\section{UNCLASSIFIED}

OFFICIAL REPORT

\section{MITTER}

Irman, Donald Edwa

E SAMPLED: $12 / 14 / 94$ 15:59:00

E RECEIVED: $12 / 15 / 94$

PLER: 29776
ADDRESS

Building 9115 MS 8219

DATE NEEDED: $12 / 29 / 94$

DATE COMPLETED: $12 / 22 / 94$

SAMPLE DESCRIPTION: GRAB

\section{CUSTOMER 10 BLDG. $9201-1$ \\ SAMPLE NO} LOCATION: GW-808 PROJECT CODE:
MTC STATUS 8601 APPROVED CHARGE \#: S2205F26 CASE: 3130

MENTS: UST WELL AT BLDG. 9201-1. RESULTS GO TO DON BOHRMAN, GW-808, 0-010117

FINAL APPROVAL:

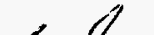

T: GRO TPH Gasoline Range Organics Including BTEX

P MTH:

NUMBER

32

414

883

0207
REPLICATE: 1 STATUS: APPROVED

TIME ANALYZED: 12/21/94 12:49:00 APPROVER: E030124

\section{DETERMINATION}

Gasol ine Range Organics

Benzene

Ethylbenzene

Toluene

Xylene

GRO Quantitation Limit

BTEX Quantitation Limit

GRO Amount in Blank
DT

\begin{tabular}{l} 
RESULT \\
\hline$<100$ \\
$10 \mathrm{U}$ \\
$10 \mathrm{U}$ \\
$10 \mathrm{U}$ \\
$<10 \mathrm{~B}$ \\
100 \\
10 \\
NONE
\end{tabular}

CONFIDENCE

UNIT

$\mathrm{ug} / \mathrm{L}$

$\mathrm{ug} / \mathrm{L}$

$\mathrm{ug} / \mathrm{L}$

ug/L

$u g / L$

$u g / L$

ug/L

$\mathrm{ug} / \mathrm{L}$ 


\section{UNCLASSIFIED}

OFFICIAL REPORT

\section{MITTER}

rman, Donald Edwa

E SAMPLED: $12 / 14 / 94$ 16:14:00

EREEIVED: $12 / 15 / 94$

PLER: 29776
ADDRESS

Building 9115 MS 8219

DATE NEEDED: $12 / 29 / 94$

DATE COMPLETED: $12 / 22 / 94$

SAMPLE DESCRIPTION: GRAB $\frac{\text { CUSTOMER ID }}{\text { BLDG. } 9201-1}$ REQ NO $\frac{\text { SAMPLE NO }}{\text { E943470084 }}$ LOCATION: GW-809

PROJECT CODE :
MTC STATUS

8601 APPROVED

CHARGE \#: S2205F26

CASE: 3130

MENTS: UST WELL AT BLDG. 9201-1. RESULTS GO TO DON BOHRMAN, GW-809, 0-010117

FINAL APPROVAL:

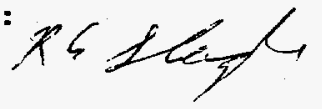

TPH Gasol ine Range Organics Including BTEX PROC MTH: SW846 8020

PHASE:

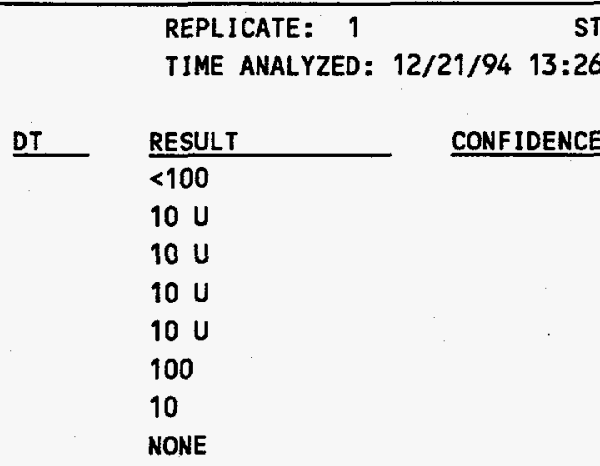

STATUS: APPROVED

MTH:

DETERMINATION

DT

Gasol ine Range Organics

Benzene

Ethylbenzene

Toluene

Xylene

GRO Quantitation Limit

BTEX Quantitation Limit

GRO Amount in Blank 


\section{UNCLASSIFIED}

OFFICIAL REPORT

04/95 11:15:00

Y-12 ANALYTICAL SERVICES ORGANIZATION

PAGE 1 OF 1

MITTER

ADDRESS

E SAMPLED: $12 / 14 / 94 \quad 14: 15: 00$

E RECEIVED: $12 / 15 / 94$

PLER: 29776

MENTS: UST MELL AT BLDG. 9201-1. RESULTS GO TO DON BOHRMAN, GW-810, 0-010117

CUSTOMER ID rman, Donald Edwa

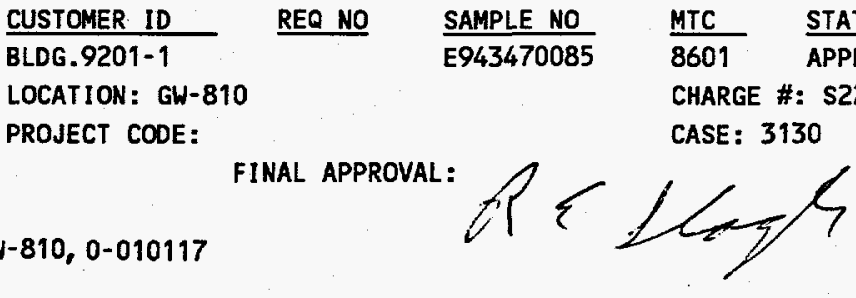
REPLICATE: 1

STATUS: APPROVED

T: GRO TPH Gasol ine Range Organics Including BTEX PROC MTH: SW846 8020 PHASE:

TIME ANALYZED: 12/21/94 14:03:00 APPROVER: E030124
NUMBER

32

414

383

0207
DETERMINATION

Gasol ine Range Organics

Benzene

Ethylbenzene

Toluene

Xylene

GRO Quantitation Limit

BTEX Quantitation Limit

GRO Amount in Blank
DT

\begin{tabular}{l} 
RESULT \\
\hline$<100$ \\
$10 \mathrm{U}$ \\
$10 \mathrm{U}$ \\
$10 \mathrm{U}$ \\
$10 \mathrm{U}$ \\
100 \\
10 \\
NONE
\end{tabular}

CONFIDENCE

UNIT

$\mathrm{ug} / \mathrm{L}$

$u g / L$

ug/L

$u g / L$

ug/L

$u g / L$

ug/L

ug/L 


\section{UNCLASSIFIED}

OFFICIAL REPORT

\section{MITTER} irman, Donald Edwa

ADDRESS

Building $9115 \quad$ MS 8219

E SAMPLED: 12/14/94 07:00:00

DATE NEEDED: $12 / 29 / 94$

FE RECEIVED: $12 / 15 / 94$

IPLER : 29776

\section{CUSTOMER ID \\ REQ NO \\ BLDG. 9201-1 \\ SAMPLE NO \\ E943470086}

LOCATION: TRIP BLANK
MTC STATUS

8601 APPROVED

CHARGE \#: S2211601

CASE : SQTO01

MENTS: TRIP BLANKS FOR UST HELL AT BLDG. 9201-1. FACILITY ID $=0-010117$.

FINAL APPROVAL:

PROJECT CODE:

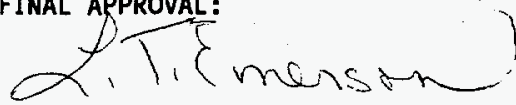

$T$ T: V0A624 Volatile Organics by GC/MS (EPA 624)

P MTH: EPA624 PROC MTH: EPA 624

PHASE:
REPLICATE: 1

STATUS: APPROVED

TIME ANALYZED: 12/15/94 15:40:00 APPROVER: E030124

\begin{tabular}{|c|c|c|c|c|}
\hline NUMBER & DETERMINATION & DT & RESULT & CONFIDENCE \\
\hline 73 & Chloromethane & & $10 U$ & \\
\hline 39 & Bromomethane & & $10 \mathrm{U}$ & \\
\hline 14 & Vinyl chloride & & $10 \mathrm{U}$ & \\
\hline 103 & Chloroethane & & $10 \mathrm{U}$ & \\
\hline 94 & Trichlorofluoromethane & & $10 \mathrm{U}$ & \\
\hline 92 & Methylene chloride & & $10 U$ & \\
\hline 54 & 1,1-Dichloroethene & & $10 \mathrm{U}$ & \\
\hline 43 & 1,1-Dichloroethane & & $10 \mathrm{U}$ & \\
\hline 605 & trans-1,2-0ichloroethene & & $10 \mathrm{U}$ & \\
\hline 63 & Chloroform & & $10 \mathrm{U}$ & \\
\hline 062 & 1,2-Dichloroethane & & $10 \mathrm{U}$ & \\
\hline 56 & 1,1,1-Trichloroethane & & $10 U$ & \\
\hline 35 & Carbon tetrachloride & & $10 \mathrm{U}$ & \\
\hline 74 & Bromodichloromethane & & $10 U$ & \\
\hline 758 & 2-Chloroethylvinyl ether & & $10 \mathrm{U}$ & \\
\hline 75 & 1,2-Dichloropropane & & $10 u$ & \\
\hline 61015 & cis-1,3-Dich loropropene & & $10 \mathrm{U}$ & \\
\hline 16 & Trichloroethene & & $10 \mathrm{U}$ & \\
\hline 481 & Dibromoch loromethane & & $10 \mathrm{U}$ & \\
\hline 05 & 1,1,2-Trichloroethane & & $10 \mathrm{U}$ & \\
\hline 32 & Benzene & & $10 u$ & \\
\hline 61026 & trans-1,3-Dichloropropene & & $10 \mathrm{U}$ & \\
\hline 52 & Bromoform & & $10 u$ & \\
\hline 184 & Tetrachloroethene & & $10 U$ & \\
\hline 45 & $1,1,2,2,-$ Tetrachloroethane & & $10 \mathrm{U}$ & \\
\hline 883 & Toluene & & $10 \mathrm{U}$ & \\
\hline 907 & Chlorobenzene & & $10 u$ & \\
\hline 414 & Ethylbenzene & & $10 \mathrm{U}$ & \\
\hline
\end{tabular}


DOE Y.12 PLANT CHAIN OF CUSTODY FORM

№ 20482

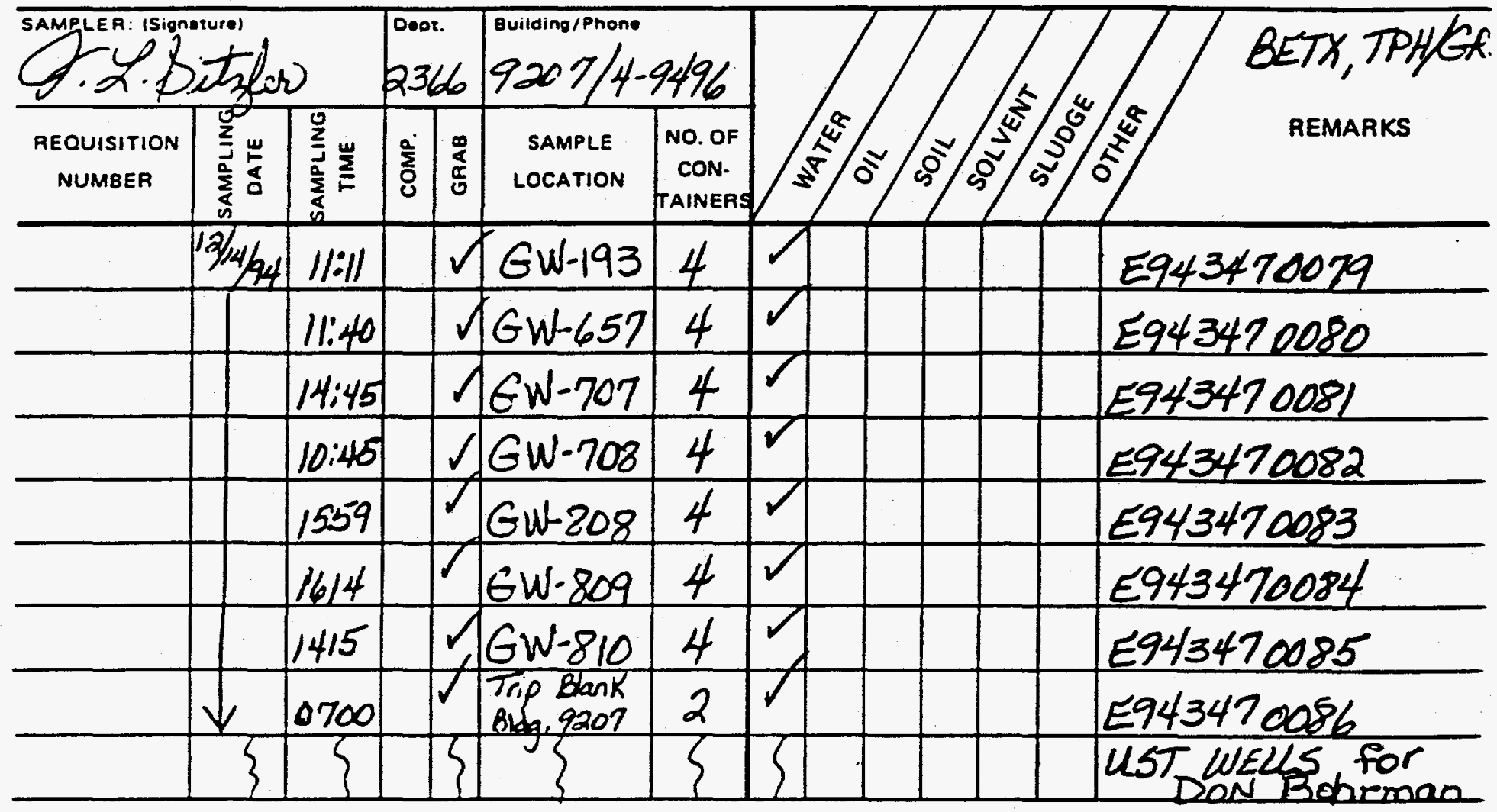




\begin{tabular}{|c|c|c|c|c|c|c|}
\hline Relpquisneg Bxigignarurg) & $\begin{array}{l}\text { Date } 1 \text { Time } \\
13 / 1 / 9 / 4,10\end{array}$ & Received By: ISignaturel & Date / Time & Dept. & $\begin{array}{l}\text { Building } \\
4207\end{array}$ & $\begin{array}{l}\text { Phone } \\
1-4\end{array}$ \\
\hline Relinquistied By: (Signarure) & Date / Time & Received By: (Signature) & Date $/$ Time & Dept. & Building & Phone \\
\hline Relinquished By. (Signature) & $\begin{array}{r}\text { Date / Time } \\
1 \\
1\end{array}$ & Received By: (Signature) & $\begin{array}{r}\text { Date / Time } \\
1 \\
\end{array}$ & Dept. & Building & Phone \\
\hline Relinquished By: (Signature) & $\begin{array}{r}\text { Date / Time } \\
1 \\
1 \\
\end{array}$ & Received By: (Signature) & $\begin{array}{r}\text { Date / Time } \\
1 \\
1 \\
\end{array}$ & Dept. & Building & Phone \\
\hline Aelinquished By: (Signature) & $\begin{array}{r}\text { Date / Time } \\
! \\
!\end{array}$ & Recerved By: (Signature) & $\begin{array}{r}\text { Date / Time } \\
1 \\
1 \\
\end{array}$ & Dept. & Building & Phone \\
\hline Reiinquished Bv: (Signature) & $\begin{array}{r}\text { Date / Time } \\
1 \\
1 \\
1\end{array}$ & Received By: (Signature) & $\begin{array}{r}\text { Date } 1 \text { Time } \\
1 \\
1 \\
\end{array}$ & Dept. & Building & Phone \\
\hline
\end{tabular}

RETURN TO ENVIRONMENTAL MONITORING, 97041, MS - 1. 43980. 


\section{DISTRIBUTION}

HEALTH, SAFETY, ENVIRONMENT AND ACCOUNTABILITY

\section{ORGANIZATION}

D.E. Bohrman (2)

L.L. Cunningham/E.M. Ingram

L.W. McMahon

File - EMD -RC

\section{MECHANICAL OPERATIONS}

ORGANIZATION

A.A. Bames

ENVIRONMENTAL COMPLIANCE

ORGANIZATION

S.H. Welch

TENNESSEE DEPARTMENT OF

ENVIRONMENT AND CONSERVATION

C. Head

E.C. Leming/J.D. Harless

\section{U. S. DEPARTMENT OF ENERGY}

E.M. Atkins

R.J. Spence/W.G. McMillan

S.R. Lankford

A. K. Lee/DOE-OSTI (2)

Y-12 Central Files 